\title{
Feeding behavior in lambs fed diets containing crambe cake
}

\section{Comportamento ingestivo de cordeiros alimentados com rações contendo torta de crambe}

\author{
Mirna Adriane Syperreck ${ }^{1 *}$; Ivone Yurika Mizubuti²; Elzânia Sales Pereira ${ }^{3}$; \\ Edson Luis de Azambuja Ribeiro²; Eduardo Lucas Terra Peixoto4; \\ Patrícia Guimarães Pimentel ${ }^{3}$; André Luiz Custódio Franco ${ }^{5}$; \\ Fernando Luiz Massaro Junior'; Rafael Mizubuti Brito'; \\ Angela Rocio Poveda Parra ${ }^{7}$
}

\begin{abstract}
It was evaluated the feeding behavior of lambs fed diets containing 30\% sorghum silage and $70 \%$ crambe cake (30:70 diet), and 70\% sorghum silage and 30\% crambe cake (70:30 diet) under voluntary and controlled consumption. The experimental design used was a $4 \times 4$ Latin square, with four animals, four periods, and four treatments; feeding behavior was determined by observation. The results indicated that animals fed the 30:70 diet showed higher DM and NDF $\left(\mathrm{g}_{\text {day }}{ }^{-1}\right)$ than those fed the 70:30 diet. Animals fed the 70:30 diet showed longer feeding times $\left(\mathrm{h} \mathrm{kg}^{-1} \mathrm{DM}\right)$, mastication ( $\mathrm{min} \mathrm{kg}^{-1} \mathrm{DM}$ and min $\mathrm{kg}^{-1} \mathrm{NDF}$ ), rumination (min day ${ }^{-1}$ and $\operatorname{min~} \mathrm{kg}^{-1} \mathrm{DM}$ ), and the largest number of mericics chewing per bolus; however, a higher feed efficiency $\left(\mathrm{g} \mathrm{DM} \mathrm{h}^{-1}\right)$ was observed in the 30:70 diet group. Furthermore, animals feeding voluntarily had higher DM intake and chewed for longer. Therefore, the combined results indicated that crambe cake could be used in the diet of sheep without affecting feeding behavior. Key words: Feeding efficiency. Mastication. Rumination. Byproduct.
\end{abstract}

\section{Resumo}

Foi avaliado o comportamento ingestivo de cordeiros alimentados com rações contendo $30 \%$ de silagem de sorgo e $70 \%$ de torta de crambe (30:70) e $70 \%$ de silagem de sorgo e $30 \%$ de torta de crambe (70:30) sob consumo voluntário e controlado. O delineamento experimental utilizado foi o quadrado latino $4 \times 4$, com quatro animais, quatro períodos e quatro tratamentos. O comportamento ingestivo foi determinado mediante observação visual. Animais recebendo dietas com relação 30:70, apresentaram maior consumo de MS e FDN $\left(\mathrm{g} \mathrm{dia}^{-1}\right)$. Animais alimentados com a relação 70:30, apresentaram maior

\footnotetext{
1 Zootecnista, Dra em Ciência Animal, Universidade Estadual do Oeste do Paraná, Unioeste, Marechal Cândido Rondon, PR, Brasil.E-mail: syperreck@gmail.com

2 Profs. Drs., Departamento de Zootecnia, Universidade Estadual de Londrina, UEL, Londrina, PR, Brasil. E-mail: mizubuti@, uel.br; elar@uel.br

${ }^{3}$ Prof $^{\text {as }} \operatorname{Dr}^{\text {as }}$, Universidade Federal do Ceará, UFC, Fortaleza, CE, Brasil. E-mail: elzania@hotmail.com; pgpimentel@hotmail.com

${ }^{4}$ Prof. Dr., Universidade Federal do Sul e Sudeste do Pará, UNIFESSPA, Campus Marabá, Nova Marabá, Marabá, PA, Brasil. E-mail: eduzootec@hotmail.com

${ }^{5}$ Zootecnista, Dr. em Ciência Animal, UEL, Londrina, PR, Brasil. E-mail: massaro@uel.br

${ }^{6} \mathrm{Eng}^{\mathrm{o}} \mathrm{Agr}^{\circ}$, Discente do Curso de Doutorado do Programa de Pós-Graduação em Ciência de Alimentos, UEL, Londrina, PR, Brasil. E-mail: rafaelmizubuti@gmail.com

${ }^{7}$ Médica Veterinária e Zootecnista, Pós-Doutoranda em Ciência Animal, Departamento de Zootecnia, UEL, Londrina, PR, Brasil. E-mail: angelapovedaparra@hotmail.com

* Author for correspondence
} 
tempo de alimentação (horas $\mathrm{kg}^{-1} \mathrm{MS}$ ), de mastigação (min $\mathrm{kg}^{-1} \mathrm{MS}$ e min $\mathrm{kg}^{-1} \mathrm{FDN}$ ), de ruminação (min dia $^{-1}$ e min $\mathrm{kg}^{-1} \mathrm{MS}$ ), maior número de mastigações merícicas por bolo. A melhor eficiência de alimentação $\left(\mathrm{g} \mathrm{MS} \mathrm{h}^{-1}\right)$ foi apresentado para a relação 30:70. Animais submetidos ao regime de consumo voluntário apresentam maior consumo de MS e maior tempo de mastigação. A torta de crambe pode ser utilizada na dieta de ovinos sem alterar os parâmetros de comportamento ingestivo.

Palavras-chave: Eficiência de alimentação. Mastigação ruminação. Subproduto.

\section{Introduction}

Sheep farming in Brazil presents high growth potential, because it provides the possibility of small- medium-, and large-scale farm development, which is stimulated by the current, rapid increase in demand for products with a high final quality, yield, and production efficiency. Therefore, to increase sustainable production, alternative and economically viable animal feed that can be digested and converted efficiently is fundamental. Given this background and increased prices of conventional animal feeds (e.g., corn and soybean), it is necessary to develop and use agribusiness coproducts such as crambe cake (Crambe abyssinica Hoechst) as alternative animal feeds. Crambe cake is obtained through the mechanical extraction of crambe seed oil, which is rich in protein (20-30\%) and energy ( $29 \%$ ), and it is therefore considered a good alternative for ruminant feeding (CANOVA et al., 2015).

Scientific, economic, and environmental factors are important in daily livestock activity for the management of diets in animal production systems. Furthermore, feeding behavior is an important tool for dietary assessments, which allows for adjustments in feeding management to enhance the production performance (CARDOSO et al., 2006; MENDOÇA et al., 2004). Feeding behavior involves aspects of nutrition and ethology, and describes the size, frequency, and duration of the meal, and the time spent feeding.

Ruminants adapt to different feeding, management, and environmental conditions, and thus, modify their feeding behavior to reach consumption levels compatible with their nutritional demands (HODGSON, 1990). For example, the main daily activities of sheep are feeding, rumination, and resting (FIGUEIREDO et al., 2013). Moreover, the most studied parameters are feeding, rumination and rest time, number of meals, periods of rumination, feeding efficiency (MACEDO et al., 2007), number of ruminating chews per bolus, time spent with chews per ruminal bolus, and number of ruminating chews per day (BÜRGER et al., 2000).

To monitor the feeding behavior of ruminants, different techniques and equipment are used. However, visual observation remains the most frequently used strategy because it is cost effective and allows detailed descriptions of the feeding behavior of animals (MEZZALIRA et al., 2011). In addition, voluntary and controlled consumption is important for housed animals that are fed in troughs (MAGGIONI et al., 2009); thus, feeding conditions may also influence feeding behavior parameters (CARDOSO et al., 2006).

Therefore, the aim of the present study was to evaluate the feeding behavior of lambs receiving sorghum silage and crambe cake diets, in different roughage:concentrate ratios and feeding regimens.

\section{Materials and Methods}

The experiment was conducted in the Laboratory of Animal Metabolism, Department of Zootechnics, State University of Londrina (UEL), (2320'23.45" $\mathrm{S}$ and $\left.51^{\circ} 12^{\prime} 32.28^{\prime \prime} \mathrm{W}\right)$, with an average temperature of $20^{\circ} \mathrm{C}$ and altitude of $532 \mathrm{~m}$. The work was approved by the Ethics Committee of Londrina State University (CEEA 60/2010). 
Four male, mongrel, castrated sheep with a mean weight of $26 \mathrm{~kg}$ were used. They were dewormed with a closantel-based commercial product. The animals were identified and housed in $0.75 \times 1.25 \mathrm{~m}$ individual cages provided with a feeder, water dispenser, and troughs for mineral supplementation.

The experimental design used a $4 \times 4$ Latin square, with four animals and four periods. Two roughage (sorghum silage, SS):concentrate (crambe cake, CC) ratios were used in the following proportions: $70 \% \mathrm{SS}$ and 30\% CC (70:30); and 30\% SS and 70\% CC (30:70); and two feeding regimens (voluntary and controlled) were followed.

The adaptation period of animals to the feeding and management routines was 10 days. The experiment was performed for 48 days, divided into four experimental periods of 12 days, with 7 days for adaptation to the experimental diets and 5 days for sample collection. The animals were individually weighed at the beginning and end of each experimental period.
The diets were given twice per day, at 0730 and 1600 , with the leftovers collected and weighed daily to determine consumption. In the voluntary consumption regimen, the feed supply was adjusted daily by the difference between the feed supplied and leftovers, per animal, to maintain leftovers of $10 \%$ of the total dry matter supplied to ensure voluntary consumption. In the controlled consumption regimen, the mean consumption was calculated for all animals in the three last days of the adaptation, and the feed provided was $90 \%$ of this mean. Water and mineral salt were continually available to the animals.

During the collection period, samples of the ingredients were collected from the leftovers and feed for subsequent chemical analyses. The analyses of ingredients and experimental diets (Table 1) were performed in the Laboratory of Animal Nutrition at the Animal Science Department of the State University of Londrina, according to the methods of Weende and Van Soest described by Mizubuti et al. (2009). The total carbohydrate content was calculated according to Sniffen et al. (1992).

Table 1 Chemical composition of ingredients and diets used in the experimental feeds (\% DM).

\begin{tabular}{lcccc}
\hline \multirow{2}{*}{ Components } & \multirow{2}{*}{ Sorghum silage } & \multirow{2}{*}{ Crambe Cake } & \multicolumn{2}{c}{ Feeds } \\
\cline { 4 - 5 } Dry mass & 31.2 & 93.1 & $40: 30$ & $30: 70$ \\
Crude protein & 6.8 & 28.3 & 13.3 & 74.6 \\
Ether extract & 1.8 & 24.3 & 8.6 & 21.1 \\
NDF & 64.2 & 68.0 & 66.9 & 65.4 \\
ADF & 45.2 & 44.5 & 42.2 & 40.0 \\
Total carbohydrate & 85.9 & 42.6 & 72.9 & 55.5 \\
Organic matter & 94.6 & 95.2 & 94.8 & 95.1 \\
Mineral matter & 5.4 & 4.8 & 5.2 & 4.9 \\
\hline
\end{tabular}

$\mathrm{NDF}=$ Neutral detergent fiber, $\mathrm{ADF}=$ Acid detergent fiber.

To assess feeding behavior, the animals were observed visually on the last day of the sample collection period. For $24 \mathrm{~h}$, the mean of the number of ruminating chews per ruminal bolus and the mean time spent in the ruminating chews per ruminal bolus were estimated using a digital chronometer. The time spent in feeding, rumination, and rest were observed for $24 \mathrm{~h}$, at a 
visual interval of $10 \mathrm{~min}$ (JOHNSON; COMBS, 1991). Throughout the experimental period, artificial light was maintained in the environment for $24 \mathrm{~h}$.

The data on feed consumption frequency and percentage distribution of rumination activities were not analyzed statistically, but described using mean frequency of consumption and rumination. The remaining data were analyzed using an analysis of variance (ANOVA), and the means obtained were compared by the Tukey test at $5 \%$ probability, using the statistical package SAS (2001). In addition, contrasting studies were performed to test the differences between the feeding regimens (voluntary vs. controlled) and SS:CC ratio in the feed (70:30 and 30:70).

\section{Results and Discussion}

Ruminants are diurnal, and when housed, feed for longer, particularly at the end of the afternoon and beginning of the morning; however, this behavior may vary when the temperature is high during the day (FORBES, 1995). The results indicated that the highest ingestion occurred from $05 \mathrm{~h} 00$ to $00 \mathrm{~h} 50$ (Figure 1). Therefore, consumption in this period may have been affected by temperature, which was very low during the night.

Figure 1 Frequency of feed ingestion (\%) in sheep receiving feeds containing different ratios of sorghum silage and crambe cake (70:30 and 30:70), under voluntary and controlled regimens, for $24 \mathrm{~h}$, subdivided into three periods.

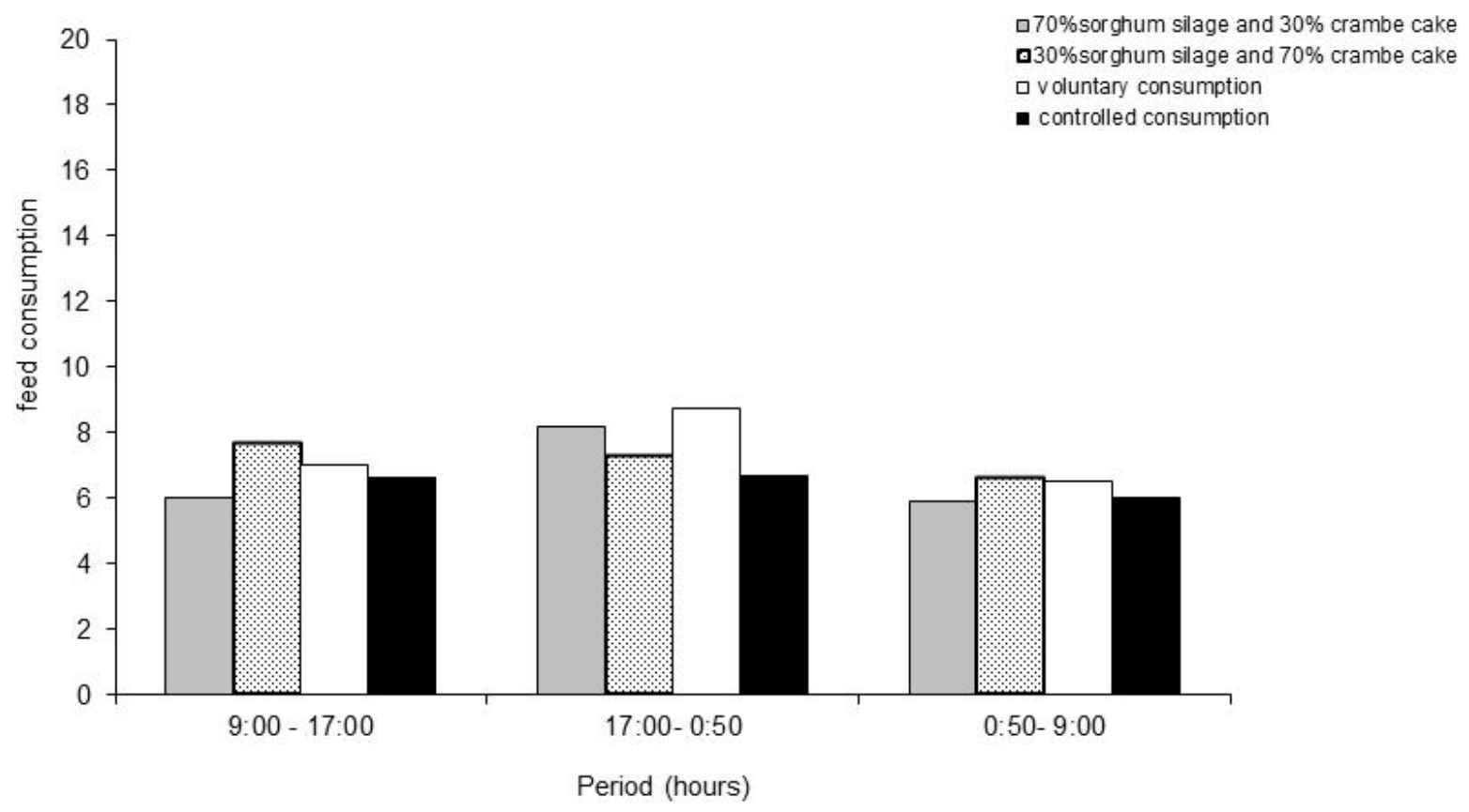

The time spent ingesting feed is usually intercalated with one or more rumination or rest periods (DESWYSEN et al., 1993), and the time spent during rumination is normally greater during the night, when air temperature is moderate (POLLI et al., 1996). The results indicated higher rumination activity occurred during the night, regardless of the silage to crambe cake ratios and feeding regimens (Figure 2). According to Lima et al. (2014), rumination frequency in sheep occurs in irregular intervals throughout the day and night, and a greater rumination frequency may occur in the morning and 
afternoon; nevertheless, these tendencies cannot be considered as characteristics of all sheep breeds.

It was determined that animals fed the 30:70 diet and animals under the voluntary regimen showed greater DM and NDF consumption (Table 2). This consumption may have been influenced by the size of crambe cake particles, which could affect the mean time of feeding retention, and consequently influence the NDF consumption (PEREIRA et al., 2008).

Figure 2 Distribution of percentage of rumination activities in sheep receiving feeds containing different ratios of sorghum silage and crambe cake (70:30 and 30:70), under voluntary and controlled regimens for $24 \mathrm{~h}$, subdivided into three periods.

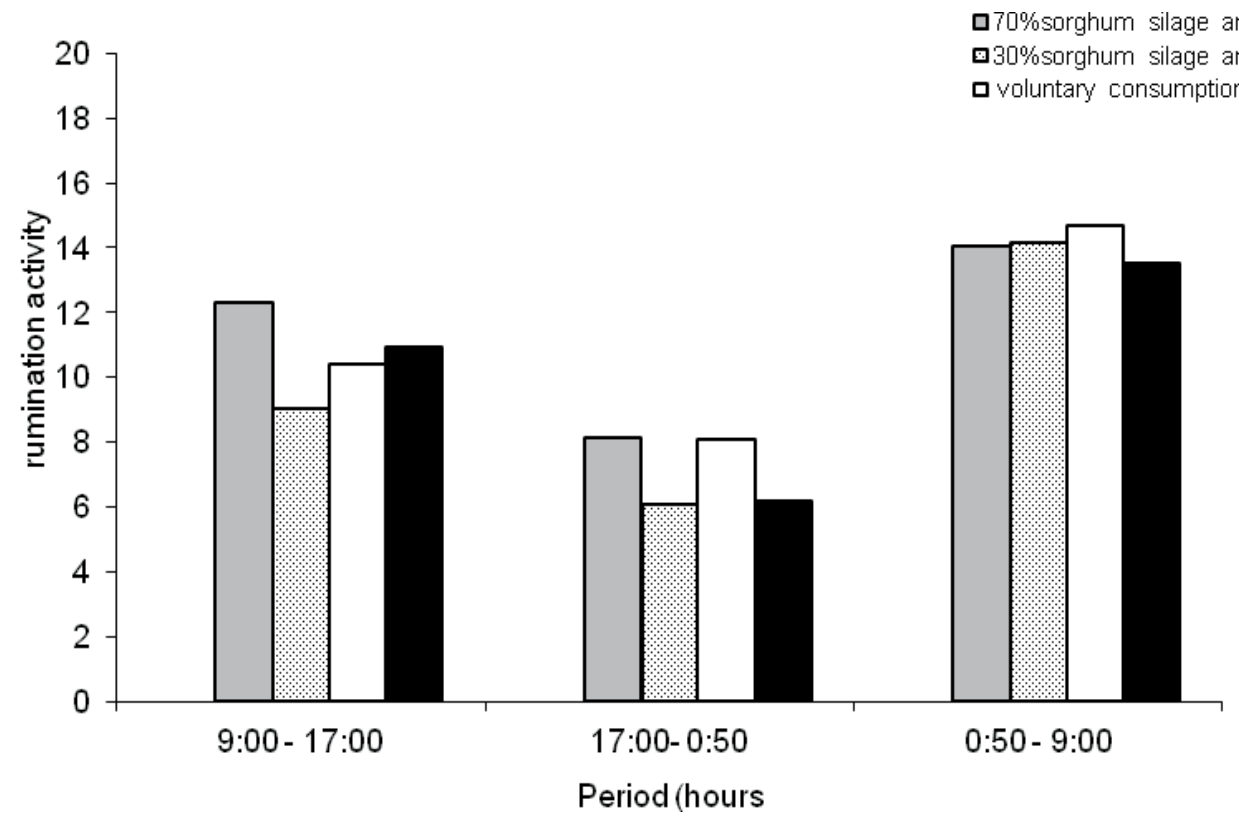

Table 2 Mean of dry matter consumption (DMC), neutral detergent fiber consumption (NDFC), and time periods spent in feeding and rumination.

\begin{tabular}{|c|c|c|c|c|c|c|c|c|}
\hline \multirow{2}{*}{ Variables } & \multicolumn{3}{|c|}{ Ratios } & \multirow{2}{*}{ Pvalue } & \multicolumn{3}{|c|}{ Feed regimens } & \multirow{2}{*}{ Pvalue } \\
\hline & $70: 30$ & $30: 70$ & $\mathrm{CV}$ & & $\mathrm{C}$ & $\mathrm{V}$ & $\mathrm{CV}$ & \\
\hline $\mathrm{DMC}\left(\mathrm{g} \mathrm{day}^{-1}\right)$ & $0.7 \mathrm{~b}$ & $1.01 \mathrm{a}$ & 7.12 & 0.001 & $0.74 \mathrm{~b}$ & $0.94 \mathrm{a}$ & 7.12 & 0.000 \\
\hline $\operatorname{NDFC}\left(g\right.$ day $\left.^{-1}\right)$ & $0.72 \mathrm{~b}$ & $0.84 \mathrm{a}$ & 1.68 & 0.007 & 0.71 & 0.83 & 1.68 & 0.271 \\
\hline \multicolumn{9}{|l|}{ Feeding } \\
\hline $\min$ day $^{-1}$ & 288.70 & 310.0 & 12.70 & 0.192 & $277.50 \mathrm{~b}$ & $321.20 \mathrm{a}$ & 12.70 & 0.002 \\
\hline $\mathrm{h} \mathrm{kg}^{-1} \mathrm{DM}$ & $7.21 \mathrm{a}$ & $5.10 \mathrm{~b}$ & 16.80 & 0.000 & 6.41 & 5.89 & 16.81 & 0.124 \\
\hline $\mathrm{h} \mathrm{kg}^{-1} \mathrm{NDF}$ & 7.02 & 6.09 & 20.30 & 0.199 & 6.48 & 6.63 & 12.80 & 0.225 \\
\hline \multicolumn{9}{|l|}{ Rumination } \\
\hline $\min _{\text {day }}{ }^{-1}$ & $497.51 \mathrm{a}$ & $421.50 \mathrm{~b}$ & 12.60 & 0.001 & 445.30 & 477.50 & 12.50 & 0.121 \\
\hline $\min \mathrm{kg}^{-1} \mathrm{DM}$ & $762.02 \mathrm{a}$ & $414.53 \mathrm{~b}$ & 13.61 & 0.003 & 649.01 & 526.10 & 13.61 & 0.134 \\
\hline $\min \mathrm{kg}^{-1} \mathrm{NDF}$ & 735.20 & 501.11 & 24.82 & 0.103 & 639.50 & 596.93 & 12.81 & 0.127 \\
\hline
\end{tabular}

$\mathrm{DMC}=$ dry matter consumption; NDFC $=$ neutral detergent fiber consumption; $\mathrm{CV}=$ coefficient of variation $(\%)$; $\mathrm{a}, \mathrm{b}-\mathrm{different}$ letters in a row, differ by Tukey's test $(\mathrm{P}<0.05) ; \mathrm{C}=$ Controlled; $\mathrm{V}=$ Voluntary. 
In the present study, time destined for feeding $\left(\right.$ min day $^{-1}$ ) was affected by the feeding regimens (Table 2), with lambs under the voluntary regimen taking more time to ingest the feed, thus affecting the consumption of dry matter $\left(\mathrm{g} \mathrm{day}^{-1}\right)$, especially since they were offered more feed than the controlled consumption group.

Carvalho et al. (2004) studied the effects of different levels of cocoa meal and palm kernel to replace corn and soybean meal in the concentrate, and showed that the time spent feeding was $7.70 \mathrm{~h}$ $\mathrm{kg}^{-1} \mathrm{DM}$. The present study showed similar results where the silage to crambe cake ratio affected feeding time, with the most time taken to consume the 70:30 diet. These results concurred with those of Van Soest (1994), where housed animals spent approximately $6 \mathrm{~h}$ consuming feed with low energy and high fiber contents.

In the present study, rumination time (min day $^{-1}$ and min $\mathrm{kg}^{-1} \mathrm{MS}$ ), cud chewing, and time of ruminant chewing were influenced by the roughage:concentrate ratio, which were higher for lambs feeding on the 70:30 diet (Tables 2 and
3). Considering that the diets had similar NDF quantities and the time spent in rumination, NDF was not affected by the roughage: concentrate ratios and feeding regimens. These results may be related to the particle size of sorghum silage, which stimulates animals to spend more time chewing and ruminating to process fiber in the feeding tract. These results are in agreement with those of Van Soest (1994), where the time spent ruminating was proportional to the fiber content in the consumed feed. In addition, Mertens (1987) found that feed comprising particles smaller than $1.18 \mathrm{~mm}$ passed through the rumen without requiring rumination; therefore, this should be the minimum size to stimulate chewing.

The total chewing time (TCT) in the lambs was affected by the feeding regimens (Table 3), and was higher for voluntary consumption due mainly to feed availability. The TCT values were similar to those reported by Azevedo et al. (2013), who evaluated different levels of macauba meal in lambs, and Carvalho et al. (2004) when studying the inclusion of 15 and $30 \%$ cocoa meal and palm kernel, respectively, in the concentrate feed.

Table 3 Feeding behavior in lambs fed with sorghum silage and crambe cake at 70:30 and 30:70 ratios, respectively, and subjected to controlled and voluntary feeding regimens.

\begin{tabular}{|c|c|c|c|c|c|c|c|c|}
\hline \multirow{2}{*}{ Variables } & \multicolumn{3}{|c|}{ Ratios } & \multirow{2}{*}{ Pvalue } & \multicolumn{3}{|c|}{ Feeding regimens } & \multirow{2}{*}{ Pvalue } \\
\hline & $70: 30$ & $30: 70$ & $\mathrm{CV}$ & & $\mathrm{C}$ & $\mathrm{V}$ & $\mathrm{CV}$ & \\
\hline $\mathrm{NRP}_{\text {day }^{-1}}$ & 28.80 & 31.00 & 12.70 & 0.114 & 27.70 & 32.10 & 12.71 & 0.121 \\
\hline TCT & 786.25 & 731.25 & 7.65 & 0.132 & $718.75 b$ & $798.75 a$ & 7.65 & 0.002 \\
\hline $\mathrm{NRB}_{\text {day }}{ }^{-1}$ & 386.75 & 350.05 & 12.90 & 0.120 & 346.50 & 390.35 & 12.90 & 0.213 \\
\hline NRC bolus $^{-1}$ & $56.15 \mathrm{a}$ & $49.85 b$ & 6.10 & 0.002 & 52.45 & 53.55 & 6.10 & 0.120 \\
\hline TRC bolus $^{-1}$ & $78.15 \mathrm{a}$ & $73.30 \mathrm{~b}$ & 5.20 & 0.001 & 76.80 & 74.65 & 5.20 & 0.141 \\
\hline DEM (min day $\left.{ }^{-1}\right)$ & 9.00 & 9.90 & 8.90 & 0.121 & 8.10 & 10.70 & 8.90 & 0.201 \\
\hline DRU (min day $\left.{ }^{-1}\right)$ & 38.50 & 34.60 & 12.10 & 0.135 & 34.90 & 38.20 & 12.10 & 0.141 \\
\hline $\mathrm{CT}\left(\min \mathrm{kg} \mathrm{MS}^{-1}\right)$ & $1194.90 \mathrm{a}$ & $721.50 \mathrm{~b}$ & 11.70 & 0.002 & 881.60 & 10310.10 & 11.70 & 0.111 \\
\hline $\mathrm{CT}\left(\min \mathrm{kg} \mathrm{FDN}^{-1}\right)$ & $1156.80 \mathrm{a}$ & $856.50 \mathrm{~b}$ & 10.80 & 0.000 & 994.70 & 1028.90 & 12.20 & 0.122 \\
\hline $\mathrm{FE}\left(\mathrm{g} \mathrm{MS} \mathrm{h}^{-1}\right)$ & $0.146 b$ & $202.00 \mathrm{a}$ & 13.10 & 0.001 & 0.16 & 0.185 & 13.10 & 0.132 \\
\hline $\mathrm{FE}\left(\mathrm{g} \mathrm{FDN} \mathrm{h}^{-1}\right)$ & 154.40 & 168.10 & 17.10 & 0.121 & 161.10 & 162.30 & 13.10 & 0.127 \\
\hline
\end{tabular}

$\mathrm{NRP}=$ Number of rumination periods; $\mathrm{TCT}=$ Total chewing time; $\mathrm{NRB}=$ Number of ruminal boluses; $\mathrm{NRC}=\mathrm{Number}$ of ruminating chews $;{ }^{5} \mathrm{TRC}=$ Time of ruminating chews; $\mathrm{DEM}=$ Duration of each meal; DRU $=$ Duration of the rumination; CT=Chewing time; $\mathrm{FE}=$ Feeding efficiency; $\mathrm{CV}=$ coefficient of variation (\%); $\mathrm{a}, \mathrm{b}-$ different letters in a row, differ by Tukey's test $(\mathrm{P}<0.05)$; $\mathrm{C}=$ Controlled; $\mathrm{V}=$ Voluntary. 
In the present study, the 30:70 diet presented a higher feeding efficiency than the 70:30 diet, which may have been influenced by the feed particle size (Table 3). The results obtained were lower than those found by Azevedo et al. (2013) and Figueiredo et al. (2013) who assessed different fiber sources, and Mousquer et al. (2013) who assessed sheep fed with silage. The feeding efficiency values were similar to those found in the previous studies. The remaining variables were not significantly different for the variable roughage:concentrate and feeding regimens.

\section{Conclusion}

The inclusion of crambe cake in animal feed at a 30:70 ratio under a voluntary regimen improved consumption, decreased feeding and rumination time, and enhanced feeding behavior; therefore, it could lead to sustainable, cost-effective lamb production.

\section{Acknowledgments}

The authors would like to thank the agronomist Carlos Pitol and the MS Foundation for Research and Dissemination of Agricultural Technology (Fundação MS para Pesquisa e Difusão de Tecnologias Agropecuárias), for providing the feedstock used in this study. The authors would also like to thank the Araucaria Foundation (Fundação Araucária de Apoio ao Desenvolvimento Científico e Tecnológico do Estado do Paraná) for financial resource.

\section{References}

AZEVEDO, R. A.; RUFINO, L. M. A.; SANTOS, A. C. R.; RIBEIRO JÚNIOR, C. S.; RODRIGUEZ, N. M.; GERASEEV, L. C. Comportamento ingestivo de cordeiros alimentados com torta de macaúba. Arquivo Brasileiro de Medicina Veterinária e Zootecnia, Belo Horizonte, v. 65, n. 2, p. 490-496, 2013.
BÜRGER, P. J.; PEREIRA, J. C.; QUEIROZ, A. C.; SILVA, J. F. C.; VALADARES FILHO, S. C.; CECON, P. R. E.; CASALI, A. D. P. Comportamento ingestivo em bezerros holandeses alimentados com dietas contendo diferentes níveis de concentrados. Revista Brasileira de Zootecnia, Viçosa, MG, v. 29, n. 1, p. 236-242, 2000.

CANOVA, E. B.; BUENO, M. S.; MOREIRA, L. M.; POSSENTI, R.; BRAS, P. Torta de crambe (Crambe abyssinica hochst) na alimentação de cordeiros. Ciência e Agrotecnologia, Lavras, v. 39, n. 1, p. 75-85, 2015.

CARDOSO, A. R.; CARVALHO, S.; GALVANI, D. B.; PIRES, C. C.; GASPERIN, B. G.; GARCIA, R. P. A. Comportamento ingestivo de cordeiros alimentados com dietas contendo diferentes níveis de fibra em detergente neutro. Ciência Rural, Santa Maria, v. 36, n. 2, p. 604609, 2006

CARVALHO, G. G. P.; PIRES, A. J. V.; SILVA, F. F.; VELOSO, C. M.; SILVA, R. R.; SILVA, H. G. O.; BONOMO, P.; MENDONÇA, S. S. Comportamento ingestivo de cabras leiteiras alimentadas com farelo de cacau ou torta de dendê. Pesquisa Agropecuária Brasileira, Brasília, v. 39, n. 9, p. 919-925, 2004.

DESWYSEN, A. G.; DUTILLEUL, P.; GODFRIN, J. P. Nycterohemeral eating and ruminating pattern in heifers fed grass or corn silage: analysis by finite Fourier transform. Journal of Animal Science, Champaign, v. 71, n. 10, p. 2739-2747, 1993.

FIGUEIREDO, M. R. P.; SALIBA, E. O. S.; BORGES, I.; REBOUÇAS, G. M. N.; AGUIAR E SILVA, F.; SÁ, H. C. M. Comportamento ingestivo de ovinos alimentados com diferentes fontes de fibra. Arquivos de Medicina Veterinária e Zootecnia, Belo Horizonte, v. 65, n. 2, p. 485-489, 2013.

FORBES, J. M. Voluntary food intake and diet selection in farm animals. Wallingford: CAB International Book, 1995. $532 \mathrm{p}$.

HODGSON, J. Grazing management: science into practice. Harlow: Longman Scientific \& Technical, 1990. $203 \mathrm{p}$.

JOHNSON, T. R.; COMBS, D. K. Effects of prepartum diet, inert rumen bulk, and dietary polyethylene glycol on dry matter intake of lactating dairy cows. Journal of Dairy Science, Champaign, v. 74, n. 3, p. 933-944, 1991.

LIMA, C. B.; COSTA, T. G. P.; NASCIMENTO, T. L.; LIMA JÚNIOR, D. M.; SILVA, M. J. M. S.; MARIZ, T. M. A. Comportamento ingestivo e respostas fisiológicas de ovinos em pastejo no semiárido. Journal of Animal Behaviour and Biometeorology, Mossoro, v. 2, n. 1, p. 26-34, 2014. 
MACEDO, C. A. B.; MIZUBUTI, I. Y.; MOREIRA, F. B.; PEREIRA, E. S.; RIBEIRO, E. L. A.; ROCHA, M. A.; RAMOS, B. M. O.; MORI, R. M.; PINTO, A. P.; ALVES, T. C.; CASIMIRO, T. R. Comportamento ingestivo de ovinos recebendo dietas com diferentes níveis de bagaço de laranja em substituição à silagem de sorgo na ração. Revista Brasileira de Zootecnia, Viçosa, MG, v. 36, n. 6, p. 1910-1916, 2007.

MAGGIONI, D.; MARQUES, J. A.; ROTTA, P. P.; ZAWADZKI, F.; ITO, R. H.; PRADO, I. N. Ingestão de alimentos. Semina: Ciências Agrárias, Londrina, v. 30, n. 4, p. 963-974, 2009.

MENDONÇA, S. S.; CAMPOS, J. M. S.; FILHO, V. S. C.; VALADARES, R. F. D.; SOARES, C. A.; LANA, R. P.; QUEIROZ, A. C.; ASSIS, A. J.; PEREIRA, M. L. A. Comportamento ingestivo de vacas leiteiras alimentadas com dietas à base de cana-de-açúcar ou silagem de milho. Revista Brasileira de Zootecnia, Viçosa, MG, v. 33, n. 3, p. 723-728, 2004.

MERTENS, D. R. Predicting intake and digestibility using mathematical models of ruminal function. Journal of Animal Science, Champaign, v. 64, n. 5, p. 1548-1558, 1987.

MEZZALIRA, J. C.; CARVALHO, P. C. F.; FONSECA, L.; BREMM, C.; REFFATTI, M. V.; POLI, C. H. E. C.; TRINDADE, J. K. Aspectos metodológicos do comportamento ingestivo de bovinos em pastejo. Revista Brasileira de Zootecnia, Viçosa, MG, v. 40, n. 5, p. 11141120, 2011.
MIZUBUTI, I. Y.; PINTO, A. P. P.; RAMOS, B. M. O.; PEREIRA, E. S. Métodos laboratoriais de avaliação de alimentos para animais. Londrina: EDUEL, 2009. 228 p.

MOUSQUER, C. J.; FERNANDES, G. A.; CASTRO, W. J. R.; HOFFMANN, A.; SIMIONI, T. A.; FERNANDES, F. F. D. Comportamento ingestivo de ovinos confinados com silagens. Revista Brasileira de Higiene e Sanidade Animal, Cuiabá, v. 7, n. 2, p. 301-322, 2013.

PEREIRA, M. S.; RIBEIRO, E. L. A.; MIZUBUTI, I. Y.; ROCHA, M. A.; KURAOKA, J. T.; NAKAGHI, E. Y. O. Consumo de nutrientes e desempenho de cordeiros em confinamento alimentados com dietas com polpa cítrica úmida prensada em substituição à silagem de milho. Revista Brasileira de Zootecnia, Viçosa, MG, v. 37, n. 1, p. 134-139, 2008.

POLLI, V. A.; RESTLE, J.; SENNA, D. B.; ALMEIDA, S. R. S. Aspectos relativos à ruminação de bovinos $\mathrm{e}$ bubalinos em regime de confinamento. Revista Brasileira de Zootecnia, Viçosa, MG, v. 25, n. 5, p. 987-993, 1996.

SAS. Institute Inc. Statistical Analysis System Introductory Guide for Personal Computers. Release. Cary, NC: Sas Institute Inc., 2001.

VAN SOEST, P. J. Nutritional ecology of the ruminant. $2^{\text {th }}$ ed. Ithaca: Cornell University Press, 1994. 476 p.

SNIFFEN, C. J.; O'CONNOR, J. D.; VAN SOEST, P. J.; FOX, D. G.; RUSSELL, J. B. A net carbohydrate and protein system for evaluating cattle diets: II. Carbohydrate and protein availability. Journal of Animal Science, Champaign, v. 70, n. 7, p. 3562-3577, 1992. 